Pacific Journal of Mathematic 


\title{
A CLASS OF COUNTEREXAMPLES ON PERMANENTS
}

\section{J. CSIMA}

\begin{abstract}
A method is described to construct a strictly positive doubly stochastic matrix $A$ of order $3 k$ such that per $(x E-A)$ has at least $k$ real zeros.
\end{abstract}

Let $A$ be an irreducible doubly stochastic matrix. de Oliveira conjectured [1] that $\operatorname{per}(x E-A)$ has no real zeros or exactly one real zero depending on the parity of the order of $A$. We prove that the number of real zeros can be arbitrarily large for matrices of sufficiently large order, even or odd. We denote by $E$ the identity matrix, always assuming its order to be such that the formulae make sense.

Lemma. There exist an infinite sequence $A_{1}, A_{2}, \cdots$ of doubly stochastic matrices of order 3 and a strictly incresing sequence of real numbers $x_{1}, x_{2}, \cdots$ such that $\operatorname{per}\left(x_{t} E-A_{i}\right)<0$, for $t \leqq i, \operatorname{per}\left(x_{t} E-\right.$ $\left.A_{i}\right)>0$, for $t>i$, all $i$.

Proof. Let $0<d<1$,

$$
A_{d}=\left[\begin{array}{lll}
0 & d & 1-d \\
1-d & 0 & d \\
d & 1-d & 0
\end{array}\right] \text { and } P_{d}(x)=\operatorname{per}\left(x E-A_{d}\right) .
$$

Then $P_{d}(x)=x^{3}+3 d(1-d)(x+1)-1$, and we have $P_{d}(-1)=-2<0$, $P_{d}(1)=6 d(1-d)>0$ and $P_{d}^{\prime}(x)=3 x^{2}+3 d(1-d)>0$. Hence $P_{d}$ is strictly increasing and has precisely one real zero which lies in the interval $(-1,1)$. To each infinite sequence $\left\{d_{i}\right\} \quad\left(0<d_{i}<1\right)$ we associate the sequence $\left\{y_{i}\right\}$ where $y_{i}($ real $)$ is defined by $P_{d_{i}}\left(y_{i}\right)=0$. Since $\lim _{d \rightarrow 1} P_{d}(x)=x^{3}-1$, there exists a strictly increasing sequence $d_{1}<d_{2}<\cdots$ such that the associated sequence of the $y_{i}$ is strictly increasing. Setting $x_{1}=-1, x_{i+1}=\left(y_{i}+y_{i+1}\right) / 2$ and $A_{i}=A_{d_{i}}$ our lemma follows.

THEOREM. For arbitrary positive integer $k$ there exists a strictly positive doubly stochastic matrix $A$ of order $3 k$ such that per $(x E-A)$ has at least $k$ distinct real zeros.

Proof. Let us consider a pair of sequences $\left\{A_{n}\right\}$ and $\left\{x_{n}\right\}$ of our lemma and let $B_{k}$ be the direct sum of $A_{1}, A_{2}, \cdots, A_{k}$. Then sgn $\left[\operatorname{per}\left(x_{i} E-B_{k}\right)\right]=(-1)^{k-i+1}$ for $i \leqq k$. Let $\varepsilon>0$ and $B_{k, \varepsilon}=(1+3 k \varepsilon)^{-1}$ 
$\left[B_{k}+\varepsilon J\right]$ where $J$ is a matrix of ones. Since $\lim _{\varepsilon \rightarrow 0} B_{k, \varepsilon}=B_{k}$ there exists a positive $\varepsilon_{0}$ such that

$$
\operatorname{sgn}\left[\operatorname{per}\left(x_{i} E-B_{k, \varepsilon_{0}}\right)\right]=\operatorname{sgn}\left[\operatorname{per}\left(x_{i} E-B_{k}\right)\right]=(-1)^{k-i+1}
$$

for $i=1,2, \cdots, k+1$. Then $A=B_{k, \varepsilon_{0}}$ satisfies the requirements of the theorem.

Strictly positive matrices being irreducible, the above proof provides a method for actually constructing counterexamples for de Oliveira's conjecture. Choosing $\varepsilon_{0}$ sufficiently small, one can even guarantee that $\operatorname{per}(x E-A)$ has precisely $k$ real zeros.

\section{REFERENCE}

1. G. N. de Oliveira, A conjecture and some problems on permanents, Pacific J. 32 (1970), 495-499.

Received August 11, 1970. This research was supported in part by the National Research Council of Canada.

MCMASTER UNIVERSITY 


\title{
PACIFIC JOURNAL OF MATHEMATICS
}

\author{
EDITORS
}

\author{
H. SAMelson \\ Stanford University \\ Stanford, California 94305 \\ C. R. HoBBy \\ University of Washington \\ Seattle, Washington 98105
}

J. DugunduI

Department of Mathematics

University of Southern California

Los Angeles, California 90007

RICHARD ARENS

University of California

Los Angeles, California 90024

\section{ASSOCIATE EDITORS}

\author{
E. F. BeCKENBACH
}

B. H. NEUMANN

F. WoLF

K. YOSHIDA

\section{SUPPORTING INSTITUTIONS}

\author{
UNIVERSITY OF BRITISH COLUMBIA \\ CALIFORNIA INSTITUTE OF TECHNOLOGY \\ UNIVERSITY OF CALIFORNIA \\ MONTANA STATE UNIVERSITY \\ UNIVERSITY OF NEVADA \\ NEW MEXICO STATE UNIVERSITY \\ OREGON STATE UNIVERSITY \\ UNIVERSITY OF OREGON \\ OSAKA UNIVERSITY \\ UNIVERSITY OF SOUTHERN CALIFORNIA
}

\author{
STANFORD UNIVERSITY \\ UNIVERSITY OF TOKYO \\ UNIVERSITY OF UTAH \\ WASHINGTON STATE UNIVERSITY \\ UNIVERSITY OF WASHINGTON \\ AMERICAN MATHEMATICAL SOCIETY \\ CHEVRON RESEARCH CORPORATION \\ NAVAL WEAPONS CENTER
}

The Supporting Institutions listed above contribute to the cost of publication of this Journal, but they are not owners or publishers and have no responsibility for its content or policies.

Mathematical papers intended for publication in the Pacific Journal of Mathematics should be in typed form or offset-reproduced, (not dittoed), double spaced with large margins. Underline Greek letters in red, German in green, and script in blue. The first paragraph or two must be capable of being used separately as a synopsis of the entire paper. The editorial "we" must not be used in the synopsis, and items of the bibliography should not be cited there unless absolutely necessary, in which case they must be identified by author and Journal, rather than by item number. Manuscripts, in duplicate if possible, may be sent to any one of the four editors. Please classify according to the scheme of Math. Rev. Index to Vol. 39. All other communications to the editors should be addressed to the managing editor, Richard Arens, University of California, Los Angeles, California, 90024.

50 reprints are provided free for each article; additional copies may be obtained at cost in multiples of 50 .

The Pacific Journal of Mathematics is published monthly. Effective with Volume 16 the price per volume (3 numbers) is $\$ 8.00$; single issues, $\$ 3.00$. Special price for current issues to individual faculty members of supporting institutions and to individual members of the American Mathematical Society: $\$ 4.00$ per volume; single issues $\$ 1.50$. Back numbers are available.

Subscriptions, orders for back numbers, and changes of address should be sent to Pacific Journal of Mathematics, 103 Highland Boulevard, Berkeley, California, 94708.

PUBLISHED BY PACIFIC JOURNAL OF MATHEMATICS, A NON-PROFIT CORPORATION

Printed at Kokusai Bunken Insatsusha (International Academic Printing Co., Ltd.), 7-17, Fujimi 2-chome, Chiyoda-ku, Tokyo, Japan. 


\section{Pacific Journal of Mathematics}

\section{Vol. 37, No. $3 \quad$ March, 1971}

Mohammad Shafqat Ali and Marvin David Marcus, On the degree of the

minimal polynomial of a commutator operator ................ 561

Howard Anton and William J. Pervin, Integration on topological

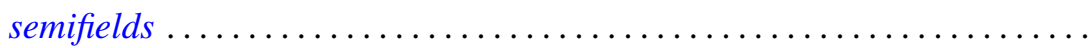

Martin Bartelt, Multipliers and operator algebras on bounded analytic

functions .................................... 575

Donald Earl Bennett, Aposyndetic properties of unicoherent continua ...... 585

James W. Bond, Lie algebras of genus one and genus two ............. 591

Mario Borelli, The cohomology of divisorial varieties ............... 617

Carlos R. Borges, How to recognize homeomorphisms and isometries ....... 625

J. C. Breckenridge, Burkill-Cesari integrals of quasi additive interval

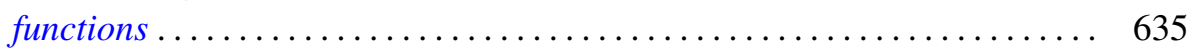

J. Csima, A class of counterexamples on permanents ................ 655

Carl Hanson Fitzgerald, Conformal mappings onto $\omega$-swirly domains . . . . . . 657

Newcomb Greenleaf, Analytic sheaves on Klein surfaces .............. 671

G. Goss and Giovanni Viglino, C-compact and functionally compact

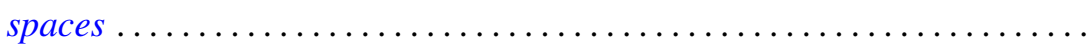

Charles Lemuel Hagopian, Arcwise connectivity of semi-aposyndetic plane

continua ..................................... 683

John Harris and Olga Higgins, Prime generators with parabolic limits ...

David Michael Henry, Stratifiable spaces, semi-stratifiable spaces, and their

relation through mappings .......................

Raymond D. Holmes, On contractive semigroups of mappings ........... 701

Joseph Edmund Kist and P. H. Maserick, BV-functions on semilattices ....... 711

Shûichirô Maeda, On point-free parallelism and Wilcox lattices ........... 725

Gary L. Musser, Linear semiprime $(p ; q)$ radicals ................. 749

William Charles Nemitz and Thomas Paul Whaley, Varieties of implicative

semilattices..................................... 759

Jaroslav Nešetřil, A congruence theorem for asymmetric trees ............ 771

Robert Anthony Nowlan, A study of $H$-spaces via left translations .......... 779

Gert Kjærgaard Pedersen, Atomic and diffuse functionals on a $C^{*}$-algebra ... 795

Tilak Raj Prabhakar, On the other set of the biorthogonal polynomials

suggested by the Laguerre polynomials...

801

Leland Edward Rogers, Mutually aposyndetic products of chainable

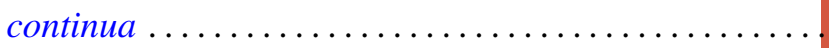

Frederick Stern, An estimate for Wiener integrals connected with squared

error in a Fourier series approximation.

Leonard Paul Sternbach, On k-shrinking and k-boundedly complete basic

sequences and quasi-reflexive spaces .................... 817

Pak-Ken Wong, Modular annihilator $A^{*}$-algebras ........ 